\title{
NOMENCLATURAL NOVELTIES IN THE BRYACEAE (BRYOPHYTA)
}

\author{
RYSZARD OCHYRA ${ }^{1}$ \& HALINA BEDNAREK-OCHYRA
}

\begin{abstract}
The taxonomic and nomenclatural history of the broadly conceived genus Bryum Hedw. is briefly outlined. Twenty-one species, originating mostly from the Southern Hemisphere and traditionally classified in this genus, have been transferred to the widely accepted segregates of Bryum, including six in Imbribryum N. Pedersen, three in Leptostomopsis (Broth.) J. R. Spence \& H. P. Ramsay, one in Plagiobryoides J. R. Spence, nine in Ptychostomum Hornsch. and two in Rosulabryum J. R. Spence.
\end{abstract}

Key words: Africa, Imbribryum, Leptostomopsis, Musci, nomenclature, Plagiobryoides, Ptychostomum, Rosulabryum, South America, Subantarctica, taxonomy

Ryszard Ochyra \& Halina Bednarek-Ochyra, Department of Bryology, W. Szafer Institute of Botany, Polish Academy of Sciences, ul.Lubicz 46,31-512 Kraków, Poland; e-mail: r.ochyra@botany.pl \&h.bednarek@botany.pl

Bryon ( $\beta \rho v ́ o v)$ is an ancient Greek name for a moss that was applied by Dillenius (1741) to one of his moss genera. The generic name Bryum Hedw. was subsequently validly published by Hedwig (1801), who placed 11 species in it. In this species composition Bryum was typically a catch-all genus; in modern moss classifications these species have been dispersed to a number of distantly related genera and families. The same was the case with the Bryaceae Schwägr., one of the earliest recognized moss families (Schwägrichen 1830), in which a similar array of unrelated genera and species was assembled. The modern concept of Bryum was outlined by Bruch et al. (1839), based primarily on European species, but this classification was subsequently developed by Brotherus (1903-1904, 1924) to include all the taxa then known worldwide.

The traditionally understood Bryum is one of the largest and most heterogeneous of moss genera, consisting of species with widely divergent morphological characters. This has resulted in many attempts to elaborate more or less workable classification systems of the genus. Generally, two opposing tendencies have been followed in muscology. Until the last decade of the twentieth

\footnotetext{
1 Corresponding author
}

century, Bryum was circumscribed very broadly as a single genus subdivided in many infrageneric taxa of various ranks, often not precisely defined, and this led to serious nomenclatural confusion (e.g., Müller 1849; Bruch et al. 1839; Schimper 1856, 1860, 1876; Podpěra 1954; Ochi 1992; Isoviita 1992; Ochyra et al. 2003).

Yet since the early days of modern muscology the opposite tendency has also been observed, characterized by segregation of some species or groups of species into genera of their own. Some of them have fallen into oblivion and have not been used since their inception, including Ptychostomum Hornsch. (Hornschuch 1822), Cladodium Brid. and Hemisynapsium Brid. (Bridel 1826), Argyro-bryum Hampe (Hampe 1876) and Argyrobryum (Müll. Hal.) Kindb. (Kindberg 1882, 1883). In contrast, other segregates, including Epipterygium Lindb. and Plagiobryum Lindb. (Lindberg 1863), Anomobryum Schimp. (Schimper 1860) and Rhodobryum (Schimp.) Limpr. (Limpricht 1892), have been accepted and are widely used in Floras, checklists and catalogues of mosses.

Because the large and heterogeneous genus Bryum has been highly impractical and could hardly be defined or defended, the second approach has gained wider acceptance in the past two 
decades. Its heterogeneity has also been confirmed by cladistic and molecular data based on DNA sequencing (Pedersen 2000; Pedersen \& Hedenäs 2002, 2003, 2005; Pedersen et al. 2003, 2007; Holyoak \& Pedersen 2007). Accordingly, the forgotten genus Ptychostomum was resurrected from obsolescence (Spence 2005) and some new segregates of the broadly conceived Bryum have been recognized, namely Rosulabryum J. R. Spence, Plagiobryoides J. R. Spence, Gemmabryum J. R. Spence \& H. P. Ramsay, Ochiobryum J. R. Spence \& H. P. Ramsay, Leptostomopsis J. R. Spence \& H. P. Ramsay and Imbribryum N. Pedersen (Spence 1996, 2005, 2007, 2009a, b; Spence \& Ramsay 2005; Pedersen 2005).

Any revolutionary taxonomic changes are indissolubly associated with nomenclatural changes which usually necessitate many transfers to the newly established or reinstated genera. This is especially the case with Bryum, which has always been considered to be one of the largest of all moss genera. Although very many species of acrocarpous mosses were given names in Bryum, especially in the early period of bryology, Ochi (1992) considered approximately 150 species to be still residual in this genus. According to Spence's (2014) calculations, however, the Bryaceae consist of about 500 species classified in 15 genera. Considering the total number of the bryalean species to be reclassified and the fairly large number of new segregates, many nomenclatural changes are unavoidable. Yet this could be minimized to some extent if some nomenclatural procedures could be judiciously applied.

It was unfortunate that Britton (1918) selected Bryum argenteum as lectotype of the genus name Bryum, since morphologically this species is very close to Anomobryum Schimp. and could easily be accommodated in that genus (Spence \& Ramsay 2002). Unfortunately, the proposal to conserve Bryum with the conserved type B. caespiticium Hedw. (Spence \& Ramsay 1999) was rejected by the Committee for Bryophyta (Zijlstra 2002) because 'Several members think that $B$. argenteum and $B$. caespiticium might be closely related. Some recent investigations (not yet published) support this, and moreover it seems that these two species are not closely related with Anomobryum'.
Rejection of this proposal has resulted in the introduction of many new combinations for species transferred to Gemmabryum, a segregate to which B. caespiticium, the unattained conserved type of Bryum, clearly belongs. This is the largest segregate of Bryum, consisting of about 100 species (Spence 2014). By no means has this decision of the Committee for Bryophyta helped to stabilize the nomenclature in accordance with the provisions of Pre. 1 and Art.14.1-2 of the current Code (McNeill et al. 2012).

Hitherto, the segregates of Bryum have been accepted in the moss Floras of Australia (Spence \& Ramsay 2006) and North America north of Mexico (Spence 2014), and all species occurring in the areas concerned were given names in the relevant genera (Spence 1996, 2005, 2007, 2009a, b, 2013; Spence \& Ramsay 2005; Ochyra et al. 2003; Pedersen 2005). In contrast, most European, Asian, African and Latin American species are still largely residual in the traditionally understood Bryum, although this genus is fairly well known taxonomically in the Neotropics (Ochi 1980, 1981), sub-Saharan Africa and adjacent islands (Ochi 1972, 1973), southern South America (Ochi 1982), Antarctica (Ochyra et al. 2008). During many years of taxonomic work on mosses in the Southern Hemisphere, we examined a lot of type specimens of well-circumscribed Bryum species. Therefore we find it of importance to make transfers of these distinct species to the proper segregates of Bryum in order to permit them to be used in taxonomic and phytogeographical considerations of austral mosses. In total, 21 new combinations are effected, including six in Imbribryum, three in Leptostomopsis, one in Plagiobryoides, nine in Ptychostomum, and two in Rosulabryum.

Imbribryum bessonii (Renauld \& Cardot) Ochyra \& Bedn.-Ochyra, comb. nov.

Bryum bessonii Renauld \& Cardot in Renauld, Suppl. Prodr. Fl. Bryol. Madagascar: 59. 1909.

\section{Imbribryum incacorrale (Herzog) Ochyra} \& Bedn.-Ochyra, comb. nov.

Bryum incacorrale Herzog, Beih. Bot. Centralbl. 26(2): 72. 1910 ['incacorralis']. 
Imbribryum microchaeton (Hampe) Ochyra

\& Bedn.-Ochyra, comb. nov.

Bryum microchaeton Hampe, Ann. Sc. Nat. Bot., Sér. 5, 4: 342. 1865.

Imbribryum orthotheciellae (Müll. Hal.) Ochyra \& Bedn.-Ochyra, comb. nov.

Bryum orthotheciellae Müll. Hal., Bot. Jahrb. 5: 78. 1883.

Imbribryum paradoxum (Welw. \& Duby) Ochyra \& Bedn.-Ochyra, comb. nov.

Bryum paradoxum Schwägr., Sp. Musc. Suppl. 3(1): t. $224 a .1827$.

Imbribryum tristaniense (Dixon) Ochyra

\& Bedn.-Ochyra, comb. nov.

Bryum tristaniense Dixon in Christoph., Results Norweg.

Sci. Exped. Tristan da Cunha 48: 30. 1960.

Leptostomopsis angolensis (Welw. \& Duby)

Ochyra \& Bedn.-Ochyra, comb. nov.

Bryum angolense Welw. \& Duby, Mém. Soc. Phys. Nat. Genève 21: 219, pl. 1, f. 4. 1870.

Leptostomopsis morasica (Besch.) Ochyra \& Bedn.-Ochyra, comb. nov.

Brachymenium morasicum Besch., Bull. Herb. Boissier 2: 392.1894.

Leptostomopsis pulchra (Hook.) Ochyra \& Bedn.Ochyra, comb. nov.

Brachymenium pulchrum Hook., Bot. Misc. 1: 136, f. 38.1829.

Plagiobryoides orbiculatifolia (Cardot \& Broth.) Ochyra \& Bedn.-Ochyra, comb. nov.

Bryum orbiculatifolium Cardot \& Broth., K. Svensk. Vet. Akad. Handl. 63(10): 42. 1923.

Ptychostomum donatii (Thér.) Ochyra \& Bedn.Ochyra, comb. nov.

Bryum donatii Thér., Rev. Bryol. Lichénol. 7: 175,f. 6. 1935.

Ptychostomum eatonii (Mitt.) Ochyra \& Bedn.Ochyra, comb. nov.

Bryum eatonii Mitt., J. Linn. Soc. Bot. 15: 195. 1876.
Ptychostomum gayanum (Mont. ex Müll. Hal.) Ochyra \& Bedn.-Ochyra, comb. nov.

Bryum gayanum Mont. ex Müll. Hal., Syn. Musc. Frond. 1: 267.1848.

Ptychostomum kerguelense (Mitt.) Ochyra

\& Bedn.-Ochyra, comb. nov.

Bryum kerguelense Mitt., J. Linn. Soc. Bot. 15: 67. 1876.

Ptychostomum mucronatum (Mitt.) Ochyra

\& Bedn.-Ochyra, comb. nov.

Bryum mucronatum Mitt. in Hook.f., Handb. New Zealand Fl.: 442. 1867.

Ptychostomum nivale (Müll. Hal.) Ochyra

\& Bedn.-Ochyra, comb. nov.

Bryum nivale Müll. Hal., Syn. Musc. Frond. 1: 262. 1848 .

Ptychostomum orthothecium (Cardot \& Broth.) Ochyra \& Bedn.-Ochyra, comb. nov.

Bryum orthothecium Cardot \& Broth., K. Svensk. Vet. Akad. Handl. 63(10): 47. 1923.

Ptychostomum revolutum (Müll. Hal.) Ochyra \& Bedn.-Ochyra, comb. nov.

Bryum revolutum Müll. Hal., Linnaea 42: 281. 1879.

Ptychostomum zeballosicum (Cardot \& Broth.) Ochyra \& Bedn.-Ochyra, comb. nov.

Bryum zeballosicum Cardot \& Broth., K. Svensk. Vet. Akad. Handl. 63(10): 44, pl. 3 f. 10. 1923.

Rosulabryum isleanum (Besch.) Ochyra \& Bedn.Ochyra, comb. nov.

Bryum isleanum Besch., Compt. Rend. Acad. Sci. Paris 81: 73.1875.

Rosulabryum pseudomarginatum (Geh. \& Hampe) Ochyra \& Bedn.-Ochyra, comb. nov.

Bryum pseudomarginatum Geh. \& Hampe, Flora 64: 375. 1881 ['pseudo-marginatum'].

AcKnowledgements. We are grateful to Rod D. Seppelt, Arundel, Australia, for checking the English. This study gained financial support through the statutory fund of the W. Szafer Institute of Botany of the Polish Academy of Sciences. 


\section{REFERENCES}

BRIDEL S. E. 1826. Bryologia universa seu systematica ad novam methodum dispositio, historia et descriptio omnium muscorum et descriptio omnium muscorum frondosorum hucusque cognitorum cum synonymia ex auctoribus probatissimis. 1. Sumtibus Joan. Ambros. Barth, Lipsiae.

Britton E. G. 1918. Class 1. Musci. Mosses. In: N. L. BritTON (ed.), Flora of Bermuda (illustrated), pp. 430-448. Charles Scribner's Sons, New York.

Brotherus V. F. 1903-1904. III. Unterklasse Bryales. II. Spezieller Teil. Bryum. In: A. Engler \& K. Prantl (eds), Die Natürlichen Pflanzenfamilien nebst ihren Gattungen und wichtigeren Arten inbesondere den Nutzpflanzen. 1(3) Musci (Laubmoose), pp. 564-598. Wilhelm Engelmann, Leipzig.

Brotherus V. F. 1924. Musci (Laubmoose). Unterklasse Bryales. II. Spezieller Teil. In: A. ENGLER (ed.), Die Natürlichen Pflanzenfamilien nebst ihren Gattungen und wichtigeren Arten inbesondere den Nutzpflanzen. 10: 143-478. Wilhelm Engelmann, Leipzig.

Bruch P., Schimper W. P. \& Gümbel W. T. 1839. Bryum. In: W. P. SCHIMPER (ed.), Bryologia europaea seu genera muscorum europaeorum monographicae illustrata. 2: 71$152+$ pls. 331-332, 334, 339-348, 351-356, 358-360, 363-376, 378-380, 382, 384 [Fasc. 6-9: 82 pp. + 41 pls.]. Sumptibus Librariae E. Schweizerbart, Stuttgartiae.

Dillenius J. J. 1741 ['1742']. Historia muscorum in qua circiter sexcentae species veteres et novae ad sua genera relatae describuntur et iconibus genuinis illustrantur: cum appendice et indice synonymorum. E Theatro Sheldoniano, Oxonii.

Hampe E. 1876. Musci novi Musei Melbournei. Continuatio. Linnaea 40: 301-326.

Hedwig J. 1801. Species muscorum frondosorum descriptae et tabulis aeneis LXXVII coloratis illustratae. Sumtu Joannis Ambrosii Barthii, Parisiis, apud Amand Koenig, Lipsiae.

Holyoak D. T. \& Pedersen N. 2007. Conflicting molecular and morphological evidence of evolution within the Bryaceae (Bryopsida) and its implications for generic taxonomy. J. Bryol. 29: 111-124.

HornsChUCH F. 1822. Ptychostomum novum muscorum frondosorum genus. Flora 5: 62-64.

IsOVIITA P. 1992. Notes on the sectional nomenclature of the Bryoideae. In: H. OCHI, A revised infrageneric classification of the genus Bryum and related genera (Bryaceae, Musci). Appendix. In: T. Koponen \& J. Hyvönen (eds), Proceedings of the Congress of East Asiatic Bryology, Helsinki, August 12-19, 1990. Bryobrothera 1: 231-244.

KINDBerg N. C. 1882. Die Familien und Gattungen der Laubmoose (Bryineae) Schwedens und Norwegens hauptsächlich nach dem Lindbergschen Systeme. Bih. Kongl. Svenska Vetensk.-Akad. Handl. 6(19): 1-25.
KindBerg N. C. 1883. Die Arten der Laubmoose (Bryineae) Schwedens und Norwegens. Bih. Kongl. Svenska Vetensk.-Akad. Handl. 7(9): 1-167.

Limpricht K. G. 1892. Die Laubmoose Deutschlands, Oesterreichs und der Schweiz. I. Abtheilung: Sphagnaceae, Andreaeaceae, Archidiaceae, Bryineae (Cleistocarpae, Stegocarpae [Acrocarpae]). Rhodobryum. In: Dr. L. Rabenhorst's Kryptogamen-Flora von Deutschland, Oesterreich und der Schweiz. Ed. 2. 4(20): 444-447. Verlag von Eduard Kummer, Leipzig.

LiNDBERG S. O. 1863. Om ett nytt slägte, Epipterygium, bland bladmossorna. Öfvers. Förhandl. Kongl. Svenska Vetensk.-Akad. 19: 599-609.

McNeill J., Barrie F. R., Buck W. R., Demoulin V., Greuter W., Hawksworth D. L., Herendeen P. S., Knapp S., Marhold K., Prado J., Prud'homme van Reine W. F., Smith G. F., Wiersema J. H. \& Turland N. J. (eds) 2012. International Code of Nomenclature for algae, fungi, and plants (Melbourne Code), adopted by the Eighteenth International Botanical Congress Melbourne, Australia, July 2011. Regnum Vegetabile 154. Koeltz Scientific Books, Königstein.

MüLlER C. 1849. Synopsis muscorum frondosorum omnium hucusque cognitorum. Pars prima - Musci vegetationis acrocarpicae. Sumptibus Alb. Foerstner, Berolini.

OCHI H. 1972. A revision of African Bryoideae, Musci (First part). J. Fac. Educ. Tottori Univ. Nat. Sci. 23: 7-126.

Ochi H. 1973. A revision of African Bryoideae, Musci (Second part). J. Fac. Educ. Tottori Univ., Nat. Sci. 24: 23-50.

OCHI H. 1980. A revision of the neotropical Bryoideae, Musci (First part). J. Fac. Educ. Tottori Univ., Nat. Sci. 29: 49-154.

OCHI H. 1981. A revision of the neotropical Bryoideae, Musci (Second part). J. Fac. Educ. Tottori Univ., Nat. Sci. 30: 21-55.

OchI H. 1982. A revision of the Bryoideae (Musci) in southern South America. J. Fac. Educ. Tottori Univ., Nat. Sci. 31: $11-47$.

OCHI H. 1992. A revised infrageneric classification of the genus Bryum and related genera (Bryaceae, Musci). In: T. KoPONEN \& J. Hyvönen (eds), Proceedings of the Congress of East Asiatic Bryology, Helsinki, August 12-19, 1990. Bryobrothera 1: 231-241(-244).

Ochyra R., Lewis Smith R. I. \& BednareK-Ochyra H. 2008. The illustrated moss flora of Antarctica. Cambridge University Press, Cambridge.

Ochyra R., Żarnowiec J. \& Bednarek-Ochyra H. 2003. Census catalogue of Polish mosses. Polish Academy of Sciences, Institute of Botany, Kraków.

Pedersen N. 2000. A cladistic overview of the Bryaceae (Musci) based on morphological and anatomical data and with emphasis on the genus Bryum. J. Bryol. 22: 193-206. 
Pedersen N. 2005. Validation of Imbribryum (Bryaceae). Bryologist 108: 449.

Pedersen N. \& Hedenäs L. 2002. Phylogenetic relationships between Bryum and supposedly closely related genera. J. Bryol. 24: 277-289.

Pedersen N. \& HedenÄs L. 2003. Phylogenetic investigations of a well supported clade within the Bryaceae: evidence from seven chloroplast sequences and morphology. Pl. Syst. Evol. 240: 115-132.

Pedersen N. \& HedenÄs L. 2005. Taxonomic and nomenclatural implications of phylogenetic studies of the Bryaceae based on molecular data and morphology. Bryologist 108: $123-128$.

Pedersen N., Cox C. J. \& Hedenäs L. 2003. Phylogeny of the moss family Bryaceae inferred from chloroplast DNA sequences and morphology. Syst. Bot. 28: 471-482.

Pedersen N., Holyoak D. T. \& Newton A. E. 2007. Systematics and morphological evolution within the moss family Bryaceae: a comparison between parsimony and Bayesian methods for reconstruction of ancestral character states. Molec. Phylogen. Evol. 43: 891-907.

PODPĚRA J. 1954. Conspectus muscorum europaeorum. Nakladatelství Československé Akademie Věd, Praha.

SCHIMPeR W. PH. 1856. Corollarium bryologiae europaeae, conspectum diagnosticum familiarum, generum et specierum, adnotationes novas atque emendationes complectens. Sumptibus librariae E. Schweizerbart, Stuttgartiae.

SCHIMPER W. PH. 1860. Synopsis muscorum europaeorum praemissa introductione de elementis bryologicis tractante. Sumptibus Librariae E. Schweizerbart, Stuttgart.

Schimper W. Ph. 1876. Synopsis muscorum europaeorum praemissa introductione de elementis bryologicis tractante. 2. Sumptibus Librariae E. Schweizerbart (E. Koch), Stuttgartiae.

SCHWÄGRICHEN CH. F. 1830. Species muscorum frondosorum.
Pars I. In: C. L. Willdenow (ed.), Caroli a Linné Species plantarum exhibentes plantas rite cognitas ad genera relatas cum differentiis specificis, nominbus trivialibus, synonymis selectis, locis natalibus secundum systema sexuale digestas. Ed. 4. 5(2[1]). Impensis G. C. Nauck, Berolini.

SPENCE J. R. 1996. Rosulabryum genus novum (Bryaceae). Bryologist 99: 221-225.

SPENCE J. R. 2005. New genera and combinations in Bryaceae (Bryales, Musci) for North America. Phytologia 87: 15-28.

Spence J. R. 2007. Nomenclatural changes in the Bryaceae (Bryopsida) for North America II. Phytologia 87: 110-114.

Spence J. R. 2009a. Nomenclatural changes in the Bryaceae (Bryopsida) for North America III. Phytologia 91: 494-500.

Spence J. R. 2009b. New combinations in North American Rosulabryum (Bryopsida, Bryaceae). Novon 19: 397-400.

SPENCE J. R. 2013. A new combination in Ptychostomum (Bryaceae, Bryophyta) for Bryum subneodamense Kindb. Phytoneuron 2013-3: 1.

Spence J. R. 2014. Bryaceae. In: Flora of North America Editorial COMmittee (ed.), Flora of North America north of Mexico. 28 Bryophyta, part 2, pp. 117-185. Oxford University Press, New York - Oxford.

Spence J. R. \& Ramsay H. P. 1999. Proposal to conserve the name Bryum (Musci, Bryaceae) with a conserved type. Taxon 48: 827-828.

Spence J. R. \& Ramsay H. P. 2005. New genera and combinations in the Bryaceae (Bryales, Musci) for Australia. Phytologia 87: 61-72.

Spence J. R. \& Ramsay H. P. 2006. Bryaceae. In: P. M. McCARTHY (ed.), Flora of Australia. 51 (Mosses 1), pp. 274-348. Australian Biological Resources Study and Melbourne, CSIRO Publishing, Canberra.

ZiJlstra G. 2002. Report of the Committee for Bryophyta: 7. Taxon 51: 793-794. 